Author version: Cont. Shelf Res.: 28(17); 2008; 2404-2416

\title{
Temporal variation of diatom benthic propagules in a monsoon influenced tropical estuary
}

\author{
Jagadish S. Patil and Arga Chandrashekar Anil* \\ Marine Corrosion and Materials Research Division, National Institute of Oceanography, \\ Dona Paula, Goa - 403 004, India
}

\begin{abstract}
Temporal variations in the diatom benthic propagule (DBP) community and its role in the phytoplankton community in a monsoon-affected tropical estuary, Zuari estuary, Goa (India) is presented. The DBP from the sediments was enumerated using an extinction dilution method (Most Probable Number method), which allows estimation of resting stages through examination of germinated vegetative cells in culture. The DBP community was dominated by planktonic species belonging to the genera Skeletonema, Fragilariopsis, Thalassiosira and Chaetoceros. Benthic propagules (BP) of S. costatum and Fragilariopsis sp. were dominant throughout the year. Between these two species, only $S$. costatum showed a linear relationship between the $\mathrm{BP}$ and planktonic cells indicating that this species is particularly important in coupling of pelagic and benthic ecosystems. During the onset and restart of monsoon after an intermittent break, water column was stratified, with a low salinity layer arising from riverine discharge and precipitation at the surface and relatively cold, saline, low oxygen waters at the bottom. Stratification favored blooming of S. costatum and Fragilariopsis sp. in nutrient rich surface and bottom waters respectively. The decline in these blooms ensuing nitrate depletion and salinity change resulted in an increased abundance of BP. Chaetoceros bloom was observed during the monsoon break as well as during nonmonsoon period and on both the occasions the decline in bloom was coupled with freshwater discharge. During the non-monsoon season, Thalassiosira blooms were encountered subsequent to high nitrate inputs. These findings suggest that in such shallow tropical regions, physical processes during monsoon (freshwater discharge) and non-monsoon seasons (currents, waves and tides) cause resuspension of diatom BP. Since light is not a limiting factor for germination in such regions, the blooming of resuspended BP depends upon nutrient availability.
\end{abstract}

Key words: estuary; planktonic diatoms; benthic propagules; monsoon; non-monsoon

Correspondence to:

Arga Chandrashekar Anil

Tel: 91(0)832-2450404

Fax: 91(0)832-2450704

E-mail: acanil@darya.nio.org 


\section{Introduction}

Planktonic diatoms, which are major components of the phytoplankton community in coastal regions, are known to form specialized resting spores or resting cells (hereafter referred as resting stages for both types) as a survival strategy to overcome unfavorable conditions. The formation of resting stages as survival alternatives, in many diatoms, during their life histories is now a well-accepted phenomenon (Garrison, 1984; Hargraves and French, 1983). Diatom resting stages are dormant stages, produced in response to certain physico-chemical conditions, such as change in temperature, salinity, $\mathrm{pH}$ and especially nutrient depletion (McQuoid and Hobson, 1996). Once resting stages are formed, they sink to the sea floor and become a part of the benthos. Benthic resting stages repopulate waters if resuspended and exposed to suitable light, temperature and nutrients (McQuoid et al., 2002). This is because germination of resting stages is regulated by several environmental factors such as light, temperature, salinity and nutrients (Eilertsen et al. 1995, McQuoid and Hobson 1995, McQuoid 2005). It has been shown that such seeding from resting stages may affect the phytoplankton community structure, depending on the seeding strategy of single species. In order to have a better understanding of the influence of diatom resting stages on the phytoplankton community structure, it is important to investigate transitions between planktonic and resting stages of species, and factors influencing these transitions. In situ evaluation of these factors will further enhance, understanding of their role in diatom life cycles, survival strategies, prediction of blooms and species succession.

At present there are few long-term in situ observations of diatom resting stage production and deposition in the marine environment. These observations are from bays, coastal waters, fjords and upwelling regions (Garrison, 1981; Itakura et al., 1997; McQuoid, 2002; McQuoid and Hobson, 1996; McQuoid et al., 2002; Pitcher, 1990). The number of resting stages deposited in sediments has been compared to the number of planktonic diatoms found in overlying waters and has contributed valuable information on seasonal patterns of sporulation and germination of several diatom species. However, information to support such studies in tropical environment, where the monsoon has tremendous influence on the physico-chemical and biological characteristics of aquatic environments is limited. A recent paper which examines the role of resting stages in a tropical environment from mesocosm experiments indicated that the species composition can be altered if a population is seeded by resting stages (Härnström et al. 2007). In this study, through time series observations, the 
environmental influence on temporal variations in the diatom benthic propagule (DBP) community and their influence on the planktonic community in a monsoon-affected tropical estuary are addressed.

\section{Materials and Methods}

\subsection{Description of Study Area}

The study site, Zuari estuary, sustains a diverse phytoplankton assemblage that is strongly influenced by the southwest monsoon, which brings drastic changes in hydrodynamic characteristics and is instrumental in the complete transformation of the phytoplankton community structure and production (Devassy and Goes 1988, Bhattathiri et al. 1976). During these period surplus amounts of river discharge from the Zuari River, as well as precipitation is added to the estuary resulting in marked changes in the physico-chemical nature of the water (Qasim and SenGupta, 1981). Based on this, each year has been classified into three seasons. The monsoon season (June-September) is followed by a recovery period during post-monsoon (October-January) and thereafter by a stable period of the pre-monsoon (February-May).

Monthly sampling of sediment and water was carried out from September 1999 to January 2001 in the Zuari estuary (Goa, central west coast of India) at a fixed location (Fig. 1). The depth at the study location is $\sim 6 \mathrm{~m}$. This estuary, which is a dynamic aquatic ecosystem exhibits a strong seasonal gradient, both in environmental variables and plankton assemblages because of tight physico-chemical and biological coupling.

\subsection{Water sampling}

Water samples were collected from surface (bucket) and $1 \mathrm{~m}$ above the sea bed (Niskin sampler). Water temperature and secchi disc depth were recorded at the sampling site. Salinity, dissolved oxygen and nutrients $\left(\mathrm{NO}_{3}-\mathrm{N}, \mathrm{NO}_{2}-\mathrm{N}, \mathrm{PO}_{4}-\mathrm{P}\right.$, and $\left.\mathrm{SiO}_{3}\right)$ were analyzed by following standard procedures. For phytoplankton enumeration, a known volume (1 L) of water sample was fixed with Lugol's iodine for microscopic analysis. In addition to diatoms other phytoplankton were also enumerated in order to evaluate the contribution of diatoms to the total phytoplanktonic community. The diatom and other phytoplankton species were enumerated in triplicate and their identifications were carried out based on the identification 
keys (Hasle and Syvertsen, 1997; Round et al., 1990; Desikachary, 1987; Subrahmanyan, 1946; 1959). Diatoms were most dominant and only the data relevant for this study has been presented here. For further statistical analysis, the data of diatom species $>4 \%$ in abundance throughout the study period was used.

\subsection{Sediment Sampling}

Sediment samples were collected using a gravity corer with an inner diameter of $4.8 \mathrm{~cm}$. The top sediment $(0-2 \mathrm{~cm})$ from 2-3 cores collected during each sampling were pooled and then sealed in air tight bags. These samples were stored in dark at $4{ }^{0} \mathrm{C}$ until further analysis i.e. within couple of weeks.

\subsection{Meteorological parameters}

Data regarding meteorological parameters like solar radiation $\left(\mathrm{MW} \mathrm{cm}^{-2}\right)$, wind speed (m sec ${ }^{-1}$ ), wind direction (degrees), air temperature $\left({ }^{0} \mathrm{C}\right)$, relative humidity (\%) and atmospheric pressure (mbar) were obtained from the Marine Instrumentation and Computer Division, NIO, Goa. The rainfall (mm), day length (h: from sunrise to sunset) and sunshine hours [the time of brightness (solar radiation $>1 \mathrm{mw} \mathrm{cm}^{-2}$ ) available in a day length] data were obtained from the Indian Meteorological Department, Panaji, Goa. For interpretation, the average of 7 consecutive days prior to sampling, inclusive of sampling day has been used.

\subsection{Enumeration of Diatom Benthic Propagules (DBP) from the Sediments}

Enumeration of viable (i.e. able to germinate) diatom cells from the sediments was carried out by an extinction dilution method (Most Probable Number method, MPN; Throndsen, 1978). A known weight (1 g) of wet sediment in triplicate was suspended in 10 $\mathrm{ml}$ of the $\mathrm{f} / 2$ culture media (Guillard and Ryther, 1962) at a concentration of $0.1 \mathrm{~g}$ wet wt $\mathrm{ml}^{-}$

1. Serial tenfold dilutions $\left(10^{-2}-10^{-5}\right)$ were made with the culture medium and then $1 \mathrm{ml}$ aliquots of diluted samples were inoculated into five replicate petridishes (35 mm) and were incubated at a temperature of $20 \pm 1{ }^{0} \mathrm{C}$ with a $12 \mathrm{~h}$ light:dark cycle. The light intensity during the incubation was $50 \mu \mathrm{mol}$ photons $\mathrm{m}^{-2} \mathrm{~s}^{-1}$. The appearance of vegetative cells of diatoms was examined microscopically (Light Microscope; Olympus BH2) after an incubation period of 6-8 d. The petridish in which vegetative cells were identified was scored as positive for each species. The MPN for a series of five tenfold dilutions of resting stage 
cells in the sediment sample (MPN g-1 wet sediment) was then calculated according to the statistical table (Throndsen, 1978). This table covers a range of five dilution steps, and a set of three dilutions have to be chosen out of the five cultured petridish to get the MPN. The relative diatom cell density $\mathrm{cm}^{-3}$ wet sediment was obtained by multiplying the MPN value with the apparent specific gravity of wet sediment (Imai and Itakura 1999). For further statistical analysis, the data of diatom species $>1 \%$ in abundance throughout the study period was used.

\subsection{Data analysis}

\subsubsection{Cluster analysis of sampling periods}

The fourth root $(\sqrt{ })$ transformed abundance data of diatoms, both planktonic diatoms and that of DBP was then used to construct a lower triangular similarity matrix using BrayCurtis coefficients. This similarity matrix was then subjected to clustering by group average method and ordination by non-metric multidimensional scaling (NMDS). There are advantages in applying more than one method, since each is based on different assumptions and may give different insights (Gray et al., 1988). In case of cluster analysis, a) the individual, once placed in a group loses its identity, b) the sequence of individuals is arbitrary and c) only the inter group relationships are shown. In view of these disadvantages, it is advisable to employ an additional method of presentation to show individual relationships such as NMDS (ordination). Cluster and ordination (NMDS) analysis were made using the software PRIMER ver. 5.

\subsubsection{Cluster analysis of species abundance}

The fourth root $(\sqrt{ } \sqrt{ })$ transformed abundance data of diatoms (both planktonic cells and DBP) was then used to construct a lower triangular dissimilarity matrix using Euclidean distance. This matrix was then subjected to clustering and ordination techniques similarly as described earlier.

\subsubsection{Spearman’s rank correlation test}

Spearman's rank correlation test was performed to evaluate the relationships between the BP and PC (dominant forms) with various observed environmental parameters that may be 
responsible for regulating their population. This test was performed using the software Statistica release 5.0 by Statsoft, after transformation of only biological data i.e. fourth root $(\sqrt{ })$.

\section{Results}

\subsection{Meteorological conditions}

Temporal variation in wind speed is shown in Fig. 2A. Maximum wind speed was observed during the onset of monsoon in April and June 2000 and in the late monsoon period (September 2000). Wind speed showed a small increase during November in both the years. Monthly profiles of wind direction are shown in the Fig. 3B and reveals that during monsoon the winds are in the southwest direction. Temporal variations in the duration of sunshine hours and solar radiation showed a definite seasonal trend (Figs. 2C-D). Low sunshine hours and solar radiation were observed during June 2000 and thereafter increased to a maximum of $10.5 \mathrm{~h}$ in April 2000 (Figs. 2C-D). Maximum rainfall was observed during June (38 mm) and decreased thereafter. During non-monsoon periods, except October 2000, the study region received traces/no rainfall (Fig. 2E). The temporal variations in air temperature, relative humidity and atmospheric pressure are shown in Figs. 2F-H. During monsoon, air temperature and atmospheric pressure was low whereas the relative humidity was high.

\subsection{Hydrographic conditions}

Surface and bottom seawater temperature ranged from a maximum of $33{ }^{0} \mathrm{C}$ and $31{ }^{0} \mathrm{C}$ (March 2000) to a minimum of $28{ }^{\circ} \mathrm{C}$ (December 1999 and August 2000) and $22{ }^{0} \mathrm{C}$ (August 2000) respectively (Fig. 3A). Thermal stratification, as judged by the difference in surface and bottom temperatures, developed from June to September 2000 and the water was vertically mixed during rest of the months. Salinity ranged between a high of 36.5 in April 2000 and a low of 17 and 18 in August and June 2000 respectively. Low salinity in the surface layer was due to freshwater influx from the Zuari River during the monsoon period. During this period, salinity stratification was also observed and existed till early postmonsoon season (except July 2000; Fig. 3B). The DO concentrations ranged from $5.6 \mathrm{ml} \mathrm{L}^{-1}$ (July 2000) - $3.3 \mathrm{ml} \mathrm{L}^{-1}$ (September 1999) in surface and $4.35 \mathrm{ml} \mathrm{L}^{-1}$ (March 2000) - $2.2 \mathrm{ml}$ $\mathrm{L}^{-1}$ (August 2000) in bottom waters respectively (Fig. 3C). DO concentrations in bottom 
waters were lower than in surface waters. The maximum difference was observed during the monsoon season. The measurement of water transparency using secchi disc, revealed that the water was less transparent during the monsoon season except during July 2000 and during the end of the post-monsoon (Fig. 3D). Secchi disc depth showed an increasing trend up to February 2000 (196 cm) except in December 1999 (45 cm), which was then followed by a decline till June $2000(87 \mathrm{~cm})$.

Nutrient concentrations showed a definite seasonal trend over the sampling period (Figs 3E-H). Maximum nutrient concentrations were found during the early phase of the monsoon. A second peak of nitrate and nitrite was observed in the years 2000 and 2001 during November-December and thus was not a mere coincidence. In addition, a surface and bottom high of $\sim 7 \mu \mathrm{M}$ nitrate was observed during April 2000. The temporal variation in nutrient concentrations at both depths followed almost a similar pattern (Figs. 3E-H).

\subsection{Diatoms from the water column and sediments}

In the present study, 89 species of diatoms have been recorded. Altogether 74 (37centrales and 37-pennales) and 73 (38-centrales and 35-pennales) diatom species were recorded from surface and bottom waters respectively (Table 1). Amongst them, maximum cell densities of 6 species (Skeletonema costatum, Chaetoceros curvisetus, Thalassiosira spp, Leptocylindrus danicus, Cerataulina bicronis, Fragilariopsis sp. and Thalassionema nitzschioides) in surface and 8 species (S. costatum, C. curvisetus, Thalassiosira spp, L. danicus, C.bicornis, Fragilariopsis sp., Nitzschia angularis, Pseudonitzschia sp. and T. nitzschioides) in bottom waters was greater than 10000 cells $\mathrm{L}^{-1}$. From the sediment, benthic propagules of 41 species (21-centrales and 20-pennales) belonging to 23 genera were recorded (Table 1). Of the 41 species, resting stage formation for 16 species belonging to 12 genera are known, while formation of resting stages for other species are unknown (Table 1). In this study, the BP of only 7 species (S. costatum, C. curvisetus, Thalassiosira spp, Fragilariopsis sp., Navicula transitans and Nitzschia panduriformis) occurred in $>100$

propagules $\mathrm{cm}^{-3}$ wet wt. of sediment. Amongst them N. transitans and N. panduriformis are the benthic diatoms. Comparison of planktonic cells and BP showed that the diatom species (except L. danicus, C.bicornis N. angularis, Pseudonitzschia spp. and T. nitzscioides) which were found above 10,000 cells $\mathrm{L}^{-1}$ in the water column were the ones dominating the benthic propagule community. 
In the water column, diatoms dominated the phytoplankton community in the surface waters (30 to 99\%) as well as in the bottom waters (77 to 99\%). The percentage of diatom abundance was maximum during monsoon, followed by post- and pre-monsoon for surface waters and, for bottom waters during post-monsoon, monsoon and pre-monsoon. The total diatom densities ranged from $8.8 \times 10^{2}-9.9 \times 10^{5}$ cells $L^{-1}$ in surface and $2.2 \times 10^{3}-1.8 \times 10^{5}$ cells $\mathrm{L}^{-1}$ in bottom waters (Fig. 4A). The relative abundance of DBP ranged up to $10^{4}$ cells $\mathrm{cm}^{-3}$ wet wt. of sediment (Fig. 4B) with maximum abundance during monsoon and early post-monsoon periods. The relative abundance of BP was maximum during the post-monsoon period of 2000 as compared to that of 1999 indicating an inter-annual variation.

The distribution of dominant diatom species exhibited significant temporal variations in the both sediment and water column. During onset (June 2000) and restart of monsoon after an intermittent break (August 2000), a single species bloom of S. costatum was observed in the surface waters whereas Fragilariopsis bloom was observed only during the onset of monsoon in bottom waters (Fig. 5A and B). Blooms of both these species were responsible for the observed high cell densities. The BP of S. costatum and Fragilariopsis were present throughout the study period and the occurrence of highest densities coincided with their blooms in the water column (Fig. 5A and B). Chaetoceros and Thalassiosira were the other dominant diatoms which formed blooms on certain occasions (Fig. 5C and D). Mixed blooms were encountered on two occasions i.e. during the monsoon break and the pre-monsoon wherein Chaetoceros was the most dominant diatom. On both the occasions, the decline in bloom coincided with an increase in the BP of Chaetoceros curvisetus (Fig. 5D). The highest abundance of Chaetoceros BP were observed after the monsoon season and thereafter their population declined as the season progressed (Fig. 5D). The highest abundance of Thalassiosira was observed during the end of post-monsoon (January 2001; Fig. 5D). The distribution of Thalassiosira in the water column showed oscillations during the nonmonsoon period. However such oscillations in the distribution of Thalassiosira BP were not observed as they persisted for most part of the year.

\subsection{Cluster analysis}

Cluster analysis of the sampling months based on abundance of planktonic diatoms at $50 \%$ similarity level revealed four and two groups for surface and bottom waters respectively. In the sediments, cluster analysis based on relative abundance of DBP at 50\% similarity level 
revealed two groups (Fig. 6A-C). Clusters I and IV for surface waters, cluster I for bottom waters and cluster II for sediments were represented by sampling periods characterized by high cell densities. The planktonic diatoms and DBP distribution portrayed a similar pattern as that of the cluster analysis when subjected to 2D NMDS ordinations (Fig. 6A'-C').

Cluster analysis divided the 29 diatom species from surface waters into 1 group and 5 ungrouped individuals (Fig. 7A). The 5 ungrouped individuals were represented by $S$. costatum, Fragilariopsis sp, Thalassiosira spp., C. curvisetus and T. nitzschioides. Blooms of these species were encountered in the surface waters. For bottom waters, cluster analysis divided the 29 species into 4 groups and two ungrouped individuals (Fig. 7B). Fragilariopsis sp. and $N$. angularis represented the ungrouped individuals as they formed blooms in the bottom waters. The species representing groups I to II formed the next major components of the bottom community in terms of abundance. Cluster analysis divided the BP of 40 diatom species into 2 clusters (Fig. 7C). Cluster I consisted of 3 species, S. costatum, Fragilariopsis sp. and Thalassiosira spp., the most dominant groups which occurred during most of the study period. Cluster II was dominated by C. curvisetus and its distribution was sporadic. Rest of the species formed a minor group as they occurred once or twice during the study period. Diatom distribution for both planktonic and DBP portrayed a similar pattern as that of the cluster analysis when subjected to 2D NMDS ordinations (Fig. 7 A'-C').

\subsection{Relationship between diatoms (both planktonic cells and BP) with observed environmental variables}

The results of Spearman's rank correlation test are presented in Table 2. The abundance of $S$. costatum, both planktonic cells as well as BP showed a significant negative correlation with surface salinity (SS) and nitrate $\left(\mathrm{SNO}_{3}\right)$ and a positive relationship with rainfall (RF). The BP of Fragilariopsis sp. showed a significant negative correlation with surface salinity (SS) and nitrate $\left(\mathrm{SNO}_{3}\right)$. The planktonic cells of this species showed a negative relationship between sunshine hours (SH) and atmospheric pressure (PR) and positive relationship with bottom phosphate $\left(\mathrm{BPO}_{4}\right)$ and silicate $(\mathrm{BSi})$, wind direction (WD) and relative humidity (RH). In case of Thalassiosira spp, the BP of Thalassiosira sp.1 showed a significant negative correlation with surface nutrients (nitrate $\left(\mathrm{SNO}_{3}\right)$, nitrite $\left(\mathrm{SNO}_{2}\right)$ and phosphate $\left.\left(\mathrm{SPO}_{4}\right)\right)$ and bottom nitrate $\left(\mathrm{BNO}_{3}\right)$ whereas its planktonic cells did not show any relation with the observed environmental parameters. The BP of $T$. subtilis showed negative 
correlation with solar radiation (SR) while its planktonic cells in surface waters showed a positive relationship with surface dissolved oxygen (SDO) and a positive relationship with $\mathrm{BPO}_{4}$ and RF were observed in bottom waters. However, the BP of Thalassiosira sp. 2 showed a negative correlation with surface phosphate $\left(\mathrm{SPO}_{4}\right)$ and $\mathrm{BNO}_{3}$. The $\mathrm{BP}$ of $C$. curvisetus showed a significant positive correlation with ST, BT, RF and a negative correlation with $\mathrm{SNO}_{2}$ and $\mathrm{BPO}_{4}$.

\section{Discussion}

In the water column, blooms of 9 species (S. costatum, C. curvisetus, Thalassiosira spp, L. danicus, C.bicornis, Fragilariopsis sp., Nitzschia angularis, Pseudonitzschia sp. and T. nitzschioides) were observed during the study period (Table 1; Figure 7A and B). However out of these, benthic propagules of only 4 species were found in the sediments. These benthic propagules (DBP) persisted round the year and their dominance followed the order of Skeletonema $>$ Fragilariopsis $>$ Thalassiosira $>$ Chaetoceros (Fig. 7C). The dominance of these species, except Fragilariopsis, in sediments was also reported in temperate regions (Itakura et al. 1997) suggesting that only planktonic forms contribute significantly to the pool of DBP in the coastal sediments. During monsoon, the period of decline in blooms of Skeletonema and Fragilariopsis coincided with the maximum abundance of their propagules in the sediment.

The abundance of benthic propagules of S.costatum was negatively correlated with nitrate and salinity (Table 2A) revealing that depletion in nitrate concentrations and change in salinity may be the likely cue, which induced $S$. costatum to form BP. Whereas for Fragilariopsis sp., although a strong relation between environmental parameters could not be

established statistically, it is possible that the combined effects like temperature decrease and nutrient depletion (especially nitrate and nitrite) in bottom waters could be the inducing factors. The decline of $C$. curvisetus bloom with the onset of monsoon and restart of the monsoon after an intermittent break was coupled with an increase in the abundance of its BP. This event coincided with the decrease in salinity due to freshwater discharge from the Zuari River (Figs. 3B and 5D). Earlier it was hypothesized that the resting stage formation is initiated by poor growth conditions in the water column (Gran, 1912). Once formed, they sink to the sediments, where they remain as benthic stages. This hypothesis is by far the most widely used interpretation for the role of resting stages in the marine environment (French and Hargraves, 1980; Garrison, 1981; Hollibaugh et al., 1981). Most authors have reported 
nitrogen depletion to be the most important environmental variable causing the dormancy in marine diatoms (Davis et al., 1980; Durbin, 1978; Hollibaugh et al., 1981; Kuwata and Takahashi, 1990; review by McQuoid and Hobson, 1996). Maximum number of resting stages may be formed during or just after a period of maximum vegetative cell division (McQuoid and Hobson, 1996; Zohary et al., 1998). The formation of resting stages can take hours, days or weeks but it is not certain how long it takes after an environmental trigger to begin sporulation (see review by McQuoid and Hobson, 1996). Once formed, most of them sink faster out of the euphotic zone into the sediments. The maximum sedimentation rate recorded for diatoms in the near by region i.e. a few kilometers away from the study site (Dona Paula Bay) was $121.5 \times 10^{4}$ cells $\mathrm{m}^{-2} \mathrm{~d}^{-1}$ (Garg and Bhaskar 2000). It has also been reported that (von Bodungen et al., 1981) such sedimentation process will be a crucial part in diatom survival strategies, as it represents the transition from a surface growing stage to a benthic or deep-water resting stage in their life cycles (Smetacek, 1985).

The diatom resting stages, which are deposited at the bottom are known to survive for a long time in the sediments (Lewis et al., 1999; McQuoid et al., 2002) and their prolonged survival (even more than a century in some freshwater species) is common but not universal (Sick-Goad et al., 1989). The resting stages of the dominant species Skeletonema, Thalassiosira and Chaetoceros recorded in the study are known not only to survive for a long term under dark conditions (Itakura et al. 1997) but also to seed the surface waters for further primary production (Carrick et al 1993). Additionally, in sediments the diatom pool persists for several months in spite of the abundance of benthic macrofauna (Hansen and Josefson, 2001). Among the dominant species, only S. costatum showed a linear relationship between the BP and planktonic cells i.e. both fugitive and vegetative cells (data not shown), indicating that this species is particularly important in coupling pelagic and benthic ecosystems. As the coupling between the benthic and pelagic stages were not studied directly (eg. via sedimentation trap), and as the sampling of the sediment included the top $2 \mathrm{~cm}$, the germinated stages might have also originated from the BP formed during previous blooms.

In this study, during monsoon, the blooms of S. costatum in surface and Fragilariopsis sp. in bottom waters were observed when the water column was stratified, with a nutrient rich low salinity layer arising from riverine discharge and precipitation at the surface and the nutrient rich cold, saline and oxygen depleted water at the bottom (Figs. 3B,E-H and 5A and B). Based on density data, it was observed that $S$. costatum bloomed twice (June and August 
2000; Fig. 5A) under similar conditions, whereas Fragilariopsis sp. bloomed once (June 2000; Fig. 5B). From these observations we hypothesize that the events during monsoon such as increased freshwater discharge supplies the nutrients and resting stages from the sediments to the surface. The resuspended cells are kept in suspension due to the presence of stratification thus giving an ample opportunity for the resting stages to grow. This may be the probable reason for the occurrence of $S$. costatum and Fragilariopsis sp. blooms during monsoon along the west coast of India (Gopinathan 1974, Mitbavkar and Anil 2002, Personal observation). Since, diatom resting stages are known to germinate only under light conditions (French and Hargraves, 1985; Hollibaugh et al., 1981), resuspension of bottom sediments into the water column is a prerequisite for the cells to germinate and grow. The resuspension might be accomplished by specific hydrodynamic conditions, which have sufficient energy to transport benthic sediments, like upwelling, strong waves, currents etc. The upwelling events have been correlated with the formation of red tides (Fiegueiras and Pazos, 1991) and Chaetoceros blooms (Pitcher et al., 1991). McQuoid et al. (McQuoid et al., 2002) reported that in their study area wind forcing, baroclinic waves and northward flow of water is a vector for the resuspension of benthic propagules and assumes that the blooms could develop if conditions were favorable for their growth.

During post and pre-monsoon periods, blooms of Thalassiosira sp. and C. curvisetus were observed (Fig. $5 \mathrm{C}$ and D). The current speed in the study area is greater during spring tide (Jayakumar S., personal communication) than the critical current speed ( $>20 \mathrm{~cm} \mathrm{~s}^{-1}$ ), which is required to resuspend the bottom sediments (Bloesch, 1994). These physical forcings could be one of the factors affecting the distribution of $\mathrm{BP}$ in the sediments through frequent resuspension. It was reported that the currents (velocity as low as $10 \mathrm{~cm} \mathrm{~s}^{-1}$ ), under natural conditions in shallow waters and waves (Beaulieu, 2003) are sufficient enough to resuspend benthic diatoms, settled phytodetritus and other sticky organic flocs to the water column. The frequent resuspension of DBP and fugitive cells (if present) due to water movements could be the reason why there were no long periods where a species is absent from the surface waters (Fig. 5C and D). Moreover, such frequent resuspension and sinking could provide cells with 'recharging' periods of brief photosynthesis without inducing germination (French and Hargraves, 1980) and it provides opportunities for diatoms with a resting stage to exploit favorable conditions for their germination and subsequent vegetative growth (Ishikawa and Furuya, 2004). The nitrate input, through regeneration (Nair, 1980) or localized origin (Qasim and SenGupta, 1981), during post and premonsoon (Figs. 3E-H) might have fueled 
the observed blooms. Interestingly, C. curvisetus bloom was observed (Fig. 5D) even though the system was nitrate limited i.e. $\mathrm{NO}_{3}: \mathrm{PO}_{4}$ ratio $<1$ (data not shown) which could be because of its adaptation to high light and low nitrate conditions (Anderson and Roels, 1981). The observations from this study indicate that in such shallow tropical regions, physical processes during monsoon (freshwater discharge) and non-monsoon season (currents, waves and tides) cause resuspension of BP. Since light is not a limiting factor for germination and growth in this area, the subsequent growth of germinated BP depends upon the nutrient availability.

\section{Acknowledgements}

We are grateful to Director National Institute of Oceanography, for his support and encouragement. We thank Dr. N. B. Bhosle for his constant encouragement. We are also thankful to Mr. K. Venkat for his help in the study. We are grateful to boatman Late Mr. Deigo Cabral, Mr. P. R. Kurle and Mr. Y. Vishwakiran for their assistance in sampling. We are thankful to two anonymous reviewers for their suggestions in improving the manuscript. The first author acknowledges the Senior Research Fellowships provided by C.S.I.R. (India). This paper is a NIO contribution.... 


\section{References}

Anderson, S.M., Roels, O.A., 1981. Effects of light intensity on nitrate and nitrite uptake and excretion by Chaetoceros curvisetus. Marine Biology 62, 257-262.

Beaulieu, S.E., 2003. Resuspension of phytodetritus from the sea floor: A laboratory flume study. Limnology and Oceanography 48, 1235-1244.

Bhattathiri, P.M.A., Devassy, V.P., Bhargava, R.M.S., 1976. Production at different trophic levels in the estuarine system of Goa. Indian Journal of Marine Sciences 5: 83-86

Bloesch, J., 1994. A review of the methods used to estimate sediment resuspension. Hydrobiologia 284, 13-18.

Carrick, H.J., Aldridge, F.J., Schelske, C.L., 1993. Wind influences phytoplankton biomass and composition in a shallow, productive lake. Limnology Oceanography 38, 1179-1192.

Davis, C.O., Hollibaugh, J.T., Seibert, D.L.R., Thomas, W.H., Harrison, P.J., 1980. Formation of resting spores by Leptocylindrus danicus (Bacillariophyceae) in a controlled experimental ecosystem. Journal of Phycology 16, 296-302.

Devassy, V.P., Goes, J.I., 1988. Phytoplankton community structure and succession in a tropical estuarine complex (Central West coast of India). Estuarine Coastal and Shelf Science 27, 671-685.

Desikachary, T.V, 1987. Diatom flora of some sediments from the Indian Ocean Region. In: Atlas of Diatoms Fascicle II. T T maps and publications private limited, 328, GST Road, Chrompet, Madras. Pp. 1-10

Durbin, E.G., 1978. Aspects of the biology of resting spores of Thalassiosira nordenskioeldii and Detonula confervacea. Marine Biology 45, 31-37.

Eilertsen, H.C., Sandberg, S., Tøllefsen, H., 1995. Photoperiodic control of diatom spore growth: a theory to explain the onset of phytoplankton blooms. Marine Ecology Progress Series 116, 303-307.

French, F.W., Hargraves, P.E., 1980. Physiological characteristics of plankton diatom resting spores. Marine Biology Letters 1, 185-95.

French, F.W., Hargraves, P.E., 1985. Spore formation in the life cycles of the diatoms Chaetoceros diadema and Leptocylindrus danicus. Journal of Phycology 21,477-483.

Fiegueiras, F.G., Pazos, Y., 1991. Hydrography and phytoplankton of the Ria De Vigo before and during a red tide of Gymnodinium catenatum Graham. Journal of Plankton Research 13, 589-608. 
Garg, A., Bhaskar, P.V., 2000. Fluxes of diatoms in the Dona Paula Bay, west coast of India. Journal of Plankton Research 22, 2125-2136.

Garrison, D.L., 1981. Monterey Bay phytoplankton II resting spore cycles in coastal diatom populations. Journal of Plankton Research 3, 137-56.

Garrison, D.L., 1984. Planktonic diatoms In: Steidinger K.A., Walker, M.L. (Eds.) Marine plankton life cycle strategies. CRC Press, Boca Raton, Florida, pp. 2-17.

Gopinathan, C.P., 1974. Seasonal abundance of phytoplankton in the Cochin backwaters. Journal of the Marine Biological Association of India 14, 568-577.

Gran, H.H., 1912. Pelagic plant life. In: Murray, J., Hort, J. (Eds.) The depths of the ocean. Macmillan Press, London, pp. 307-86.

Gray, J.S., Aschan, M., Carr, M.R., Clarke, K.R., Green, R.H., Pearson, T.H., Rosenberg, R., Warwick, R.M., 1988. Analysis of community attributes of the benthic macrofauna of Frierfjord/Langesundfjord and in a mesocosm experiment. Marine Ecology Progress Series 46, 151-165.

Guillard, R.R.L., Ryther, J.H., 1962. Studies of marine planktonic diatoms. I Cyclotella nana Husted and Detonula confervacea (Cleve) Gran. Canadian Journal of Microbiology 8, 229-239.

Hansen, J.L.S., Josefson, A.B., 2001. Pools of chlorophyll and live planktonic diatoms in aphotic marine sediments. Marine Biology 139, 289-299.

Hargraves, P.E., French, F.W., 1983. Diatom resting spores: significance and strategies. In: Fryxell, G.A., (Eds.) Survival Strategies of the Algae. Cambridge University Press, Cambridge, pp. 49-68.

Härnström, K., Godhe, A., Saravanan, A., Karunasagar, I., Karunasagar, I., Rehnstam-Holm, A. (2007) Tropical phytoplankton community development in mesocosms inoculated with different life stages. Marine Ecology Progress Series 346: 75-88

Hasle, G.R., Seventeen, E.E., 1997. Marine diatoms. In: Tomas, C.R. (Ed.) Identifying marine Phytoplankton. Academic press, New York, pp. 5-385

Hollibaugh, J.T., Seibert, D.R.L., Thomas, W.H., 1981. Observations on the survival and germination of resting spores of three Chaetoceros (Bacillariophyceae) species. Journal of Phycology 17, 1-9.

Imai, I., Itakura, S., 1999. Importance of cysts in the population dynamics of the red tide flagellate Heterosigma akashiwo (Raphidophyceae). Marine Biology 133, 755-762.

Ishikawa, A., Furuya K., 2004. The role of diatom resting stages in the onset of the spring bloom in the East China Sea. Marine Biology 145, 633-639. 
Itakura, S., Imai, I., Itoh, K., 1997. "Seed bank” of coastal planktonic diatoms in bottom sediments of Hiroshima Bay, Seto Inland Sea. Marine Biology 128, 497-508.

Kuwata, A., Takahashi, M., 1990. Life form population responses of a marine planktonic diatom Chaetoceros pseudocurvisetus, to oligotrophication in regionally upwelled water. Marine Biology 107, 503-512.

Lewis, J., Harris, A.S.D., Jones, K.J., Edmonds, R.L., 1999. Long-term survival of marine planktonic diatoms and dinoflagellates in stored sediment samples. Journal of Plankton Research 21, 343-354.

McQuoid, M.R., 2002. Pelagic and benthic environmental controls on the spatial distribution of a viable diatom propagule bank on the Swedish coast. Journal of Phycology 38, 881893.

McQuoid, M.R., 2005. Influence of salinity on seasonal germination of resting stages and composition of microplankton on the Swedish west coast. Marine Ecology Progress Series 289, 151-163.

McQuoid, M.R., Hobson, L.A., 1996. Diatom resting stages. Journal of Phycology 32, 889902.

McQuoid, M.R., Hobson, L.A., 1995. Importance of resting stages in diatom seasonal succession. Journal of Phycology 31, 44-50.

McQuoid, M.R., Godhe, A., Nordberg, K., 2002. Viability of phytoplankton resting stages in the sediments of a coastal Swedish fjord. European Journal of Phycology 37, 191-201.

Mitbavkar, S., Anil, A.C., 2002. Diatoms of the microphytobenthic community: population structure in a tropical intertidal sand flat. Marine Biology 140, 41-57.

Nair, V.R., 1980. Production and associations of zooplankton in estuarine and nearshore waters of Goa. Indian Journal of Marine Science 9, 116-119.

Pitcher, G.C., 1990. Phytoplankton seed populations of the Café Peninsula upwelling plume, with particular reference to resting spores of Chaetoceros (Bacillariophyceae) and their role in seeding upwelling waters. Estuarine, Coastal and Shelf Science 31, 1 283-301.

Pitcher, G.C., Walker, D.R., Mitchell-Innes, B.A., Moloney, C.L., 1991. Short-term variability during an anchor station study in the southern Beneguela upwelling system: phytoplankton dynamics. Progress in Oceanography 28, 39-64.

Qasim, S.Z., SenGupta, R., 1981. Environmental characteristics of the Mandovi-Zuari estuarine system in Goa. Estuarine, Coastal and Shelf Science 13, 557-578.

Round, F.E., Crawford, R.M., Mann, D.G., 1990. The Diatoms Biology and Morphology of the genera. Cambridge University Press, New York, pp. 747 
Sick-Goad, L., Stoermer, E.F., Kociolek, J.P., 1989. Diatom resting cell rejuvenation and formation: time course, species records and distribution. Journal of Plankton Research 11, 375-389.

Smetacek, V.S., 1985. Role of sinking in diatom life history cycles: ecological, evolutionary, and geological significance. Marine Biology Letters 84, 239-251.

Subrahmanyan, R., 1946. A systematic account of the marine plankton diatoms of the Madras coast. Proceedins of Indian Academy of Science 24: 85 - 197

Subrahmanyan, R., 1959. Studies on the phytoplankton of the west coast of India. Parts I and II. Proceedings of the Indian Academy of Sciences 50B, 113-187.

Throndsen, J., 1978. The dilution culture method. In: Sournia, A. (Ed.) Phytoplankton Manual UNESCO, Paris, pp. 218-224.

von Bodungen, B., Broeckel, K.V., Smetacek, V., Zeitschel, B.L., 1981. Growth and sedimentation of the phytoplankton spring bloom in the Bornholm sea (Baltic sea). In: Rheinheimer, G., Fluegel, H., Lenz, J., Zeitschel, B. (Eds.), Lower organisms and their role in the food web. Institut Fuer Meereskunde, Kiel-FRG. 5, pp. 49-60.

Zohary, T., Pollingher, V., Hadas, O., Hambright, K.D., 1998. Bloom dynamics and sedimentation of Peridinium gatunense in Lake Kinneret. Limnology and Oceanography 43, 175-186. 
Table 1. List of diatoms (both planktonic diatoms and diatom benthic propagules) recorded from the sediments and the abbreviations. * indicates the resting stages reported for the respective species or genera (Garrison 1981, Sicko-Goad et al. 1989, McQuoid and Hobson 1996, McQuoid et al. 2002, Ishikawa and Furuya 2004)

\begin{tabular}{|c|c|c|c|c|c|}
\hline & \multirow[t]{2}{*}{ Abbrev. } & \multicolumn{2}{|c|}{ Water column (Cells L ${ }^{-1}$ ) } & \multirow{2}{*}{$\begin{array}{c}\text { Sediment } \\
\text { (Cells g }{ }^{-1} \text { wet wt.) }\end{array}$} \\
\hline \multicolumn{2}{|c|}{ S. No. Taxon } & & Surface & Bottom & \\
\hline & CENTRICS & & & & \\
\hline 1 & Asteromphalus sp. & Ast.sp & 27 & 27 & \\
\hline 2 & Bacteriastrum delicatulum Cleve & Bac.del & 53 & & \\
\hline 3 & Bacteriastrum fusus & Bac.fus & & 27 & \\
\hline 4 & Bacteriastrum hyalinum Lauder & Bac.hya & 533 & 347 & \\
\hline 5 & Bacteriastrum varians & Bac.var & & 27 & \\
\hline 6 & Biddulphia granulata & Bid.gra & & & 3 \\
\hline 7 & Biddulphia rhombus (Ehrenberg) W. SM. & Odt.rho & 33 & 107 & 20 \\
\hline 8 & Cerataulina bicornis & Cer.bic & 12100 & 22167 & \\
\hline 9 & Chaetoceros calcitrans & Cha.cal & & & $2 *$ \\
\hline 10 & Chaetoceros curvisetus Cleve & Cha.cur & 18413 & 13627 & $599 *$ \\
\hline 11 & Chaetoceros diversus Cleve & Cha.div & 7787 & 1493 & \\
\hline 12 & Chaetoceros laciniosus Schütt & Cha.lac & & 227 & \\
\hline 13 & Chaetoceros lorenzianus Grunow & Cha.lor & 867 & 2160 & $35 *$ \\
\hline 14 & Chaetoceros socialis Lauder & Cha.soc & 2440 & 333 & \\
\hline 15 & Chaetoceros tenuissimus Meunier & Cha.tes & 27 & & \\
\hline 16 & Climacodium frauenfeldianum Grunow & Cli.fra & 13 & 13 & \\
\hline 17 & Corethron criophilum Castracane & Cor.cri & 267 & 347 & \\
\hline 18 & Coscinodiscus marginatus Ehrenberg & Cos.mar & 427 & 4720 & 2 \\
\hline 19 & Coscinodiscus radiatus & Cos.rad & 30 & 13 & \\
\hline 20 & Coscinodiscus sp. & Cos.sp & 340 & 133 & 2 \\
\hline 21 & Ditylum brightwellii (West) Grunow & Dit.bri & 880 & 880 & $5 *$ \\
\hline 22 & Eucampia zodiacus Ehrenberg & Euc.zoo & 267 & 2333 & \\
\hline 23 & Guinardia flaccida (Castracare) H. Peragallo & Gui.fla & 7120 & 240 & \\
\hline 24 & Helicotheca tamesis (Shrubsole) Ricard & Hel.tha & 1240 & 4827 & 9 \\
\hline 25 & Hemiaulus sinensis Greville & Hem.sin & 1013 & 300 & \\
\hline 26 & Hemidiscus sp. & Hem.sp & 80 & 133 & \\
\hline 27 & Lauderia annulata Cleve & Lau.bor & 613 & 267 & \\
\hline 28 & Leptocylindrus danicus Cleve & Lep.dan & 12133 & 21033 & $3 *$ \\
\hline 29 & Melosira granulata & Mel.gra & & & $4 *$ \\
\hline 30 & Melosira nummuloides C.A. Agardh & Mel.num & 600 & 260 & 3 \\
\hline 31 & Odontella aurita (Lyngbye) Agardh & Odt.aur & & & $5 *$ \\
\hline 32 & Odontella regia & Odt.reg & 33 & 300 & 1 \\
\hline 33 & Odontella sinensis (Greville) Grunow & Odt.sin & 1000 & 495 & 12 \\
\hline 34 & Paralia sulcata (Ehrenberg) Cleve & Par.sul & 107 & 107 & $2 *$ \\
\hline 35 & Planktoniella sol (Wallich) Schutt & Pln.sol & 67 & 400 & \\
\hline 36 & Proboscia alata (Brightwell) Sundstrom & Rhi.ala & 1373 & 1307 & \\
\hline 37 & Rhizosolenia imbricata Brightwell & Rhi.imb & 53 & & \\
\hline 38 & Rhizosolenia styliformis Brightwell & Rhi.sty & & 187 & \\
\hline 39 & Rhizosolenia stolterfothii H Peragallo & Rhi.sto & 1067 & 300 & $2 *$ \\
\hline 40 & Schroederella shcroderi (Bergon) Pavillard & Sch.sch & 267 & 1040 & \\
\hline 41 & Skeletonema costatum Greville (Cleve) & Ske.cos & 992667 & 22720 & $6144 *$ \\
\hline 42 & Thalassiosira subtilis (Ostenfeld) Gran & Tha.sub & 2113 & 827 & $2581 *$ \\
\hline 43 & Thalassiosira eccentrica (Ehrenberg) Cleve & Tha.exc & 320 & 320 & \\
\hline 44 & Thalassiosira sp1. & Tha.sp1 & 30360 & 10707 & $891 *$ \\
\hline 45 & Thalassiosira sp2. & Tha.sp2 & 453 & 453 & $996 *$ \\
\hline
\end{tabular}


Continued.....

\begin{tabular}{|c|c|c|c|c|c|}
\hline \multirow[t]{2}{*}{ S. No. } & \multirow[t]{2}{*}{ Taxon } & \multirow[t]{2}{*}{ Abbrev. } & \multicolumn{2}{|c|}{ Water column (Cells L ${ }^{-1}$ ) } & \multirow{2}{*}{$\begin{array}{c}\text { Sediment } \\
\text { (Cells g }{ }^{-1} \text { wet wt.) }\end{array}$} \\
\hline & & & Surface & Bottom & \\
\hline & PENNATES & & & & \\
\hline 46 & Achnanthes longipes Agardh & Ach.lon & 1453 & 107 & \\
\hline 47 & Achnanthes subsessilis Kutzing & Ach.sub & & 13 & \\
\hline 48 & Amphiprora gigantica & Amp.gig & 80 & 27 & \\
\hline 49 & Amphora coffeaeformis (Ag.) Kützing & Amp.cof & & 27 & $47 *$ \\
\hline 50 & Amphora rostrata & Amp.ros & & 80 & 6 \\
\hline 51 & Amphora sp. & Amp.Sp & 213 & 507 & 9 \\
\hline 52 & Asterionellopsis glacialis (Castracane) Round & Ast.jap & 1920 & 1200 & $50 *$ \\
\hline 53 & Cocconeis scutellum Ehrenberg & Coc.scu & 33 & 133 & 2 \\
\hline 54 & Cylindrotheca closterium (Ehrenberg) Smith & Cy.clos & 2787 & 1493 & 14 \\
\hline 55 & Cymbella gastroides Kütz & Cym.gas & 13 & 80 & \\
\hline 56 & Diploneis sp. & Dip.sp & 27 & 80 & \\
\hline 57 & Fragilariopsis sp. & Frag.sp & 13733 & 116587 & $5712 *$ \\
\hline 58 & Grammatophora marina (Lyngbye) Kützing & Gra.mar & 93 & & \\
\hline 59 & Haslea sp. & Has. sp & 213 & 267 & \\
\hline 60 & Licmophora juergensii Agardh & Lic.jeu & 7813 & 27 & \\
\hline 61 & Licmophora paradoxa & Lic.par & 400 & & \\
\hline 62 & Meuniera membranacea (Cleve) P. C. Silva comb. nov & Meu.mem & & & 26 \\
\hline 63 & Navicula crucicula (Wm. Smith) Donkin & Nav.cru & & & 17 \\
\hline 64 & Navicula transitans var. derasa f. delicatula Heimdal & Nav.del & 8333 & 2053 & 172 \\
\hline 65 & Navicula subinflata Grun & Nav.sub & 50 & 67 & 11 \\
\hline 66 & N. inflexa & Nav.inf & & & 41 \\
\hline 67 & Navicula sp. 1 & Nav.sp1 & 573 & 693 & 33 \\
\hline 68 & Navicula sp. 2 & Nav.sp2 & 53 & 13 & 23 \\
\hline 69 & Navicula sp. 3 & Nav.sp3 & 27 & & \\
\hline 70 & Navicula sp. 4 & Nav.sp4 & 367 & & \\
\hline 71 & Nitzschia angularis & Nit.ang & 507 & 53627 & 31 \\
\hline 72 & Nitzschia bilobata & Nit.bil & 213 & 427 & 81 \\
\hline 73 & Nitzschia longissima Ralfs in Pritchard. & Nit.lon & 347 & 213 & \\
\hline 74 & Nitzschia panduriformis Gregory & Nit.pan & 160 & 213 & 130 \\
\hline 75 & Nitzschia sigma (Kützing)Wm.smith & Nit.sig & 507 & 667 & \\
\hline 76 & Pleurosigma angulatum Sensu W. Smith & Ple.ang & 6373 & 7680 & \\
\hline 77 & Pleurosigma elongatum WM Smith & Ple.elo & 133 & 33 & \\
\hline 78 & Pseudo-nitzschia (Seriata group) & Pnit.ser & 3767 & 30987 & 5 \\
\hline 79 & Pseudo-nitzschia sp. 1 & Pnit.sp1 & 393 & 160 & \\
\hline 80 & Pseudo-nitzschia sp. 2 & Pnit.sp2 & 67 & & \\
\hline 81 & Surirella ovata & Sur.ova & 133 & 213 & \\
\hline 82 & Surirella sp. & Sur.sp & 27 & 80 & \\
\hline 83 & Synedra gallioni (Bory) Ehrenberg & Syn.gal & 53 & 53 & \\
\hline 84 & Synedra affinis Kützing & Syn.aff & 53 & 107 & \\
\hline 85 & Synedra sp. & Syn.sp & 93 & 53 & \\
\hline 86 & Thalassionema frauenfeldii (Grunow) Hallegraeff & Thx.fre & 3120 & 960 & \\
\hline 87 & Thalassionema nitzschioides (Grunow) & Thn.nit & 27067 & 12587 & 45 \\
\hline 88 & Thalassiothrix longissima Cleve and Grunow & Thx.lon & 1920 & 1493 & \\
\hline 89 & Unidentified sp. & UI & & & 10 \\
\hline
\end{tabular}


Table 2. Results of Spearman's rank correlation test between 24 environmental variables and total diatom benthic propagules (DBP) as well as the benthic propagules and planktonic cells of Skeletonema costatum, Fragilariopsis sp., Thalassiosira subtilis, $T$. sp.1, T. sp.2 and Chaetoceros curvisetus. Only the combinations with significance level $>95 \%$ are shown.

Note: ST-surface temperature; SS-surface salinity; $\mathrm{SNO}_{3}$-surface nitrate; $\mathrm{SNO}_{2}$-surface nitrite; $\mathrm{SPO}_{4}$-surface phosphate; SSi-surface silicate; BT-bottom temperature; BDObottom dissolved oxygen; $\mathrm{BNO}_{3}$-bottom nitrate; $\mathrm{BPO}_{4}$-bottom phosphate; BSi-bottom silicate; WV-wind velocity; WD-wind direction; SH-sunshine hours; SR-solar radiation; RF-rainfall; RH-relative humidity; PR-atmospheric pressure

\begin{tabular}{|c|c|c|c|c|c|c|c|c|c|c|c|c|c|c|}
\hline \multirow[t]{2}{*}{ Parameters } & \multirow{2}{*}{$\begin{array}{c}\text { DBP } \\
\mathrm{R}\end{array}$} & \multicolumn{3}{|c|}{ S. costatum } & \multicolumn{2}{|c|}{ Fragilariopsis sp. } & \multicolumn{2}{|l|}{ T. subtilis } & \multicolumn{2}{|l|}{ T. sp.1 } & \multicolumn{2}{|l|}{ T. sp.2 } & \multicolumn{2}{|c|}{ C.curvisetus } \\
\hline & & $p$ & $\mathrm{R}$ & $p$ & $\mathrm{R}$ & $p$ & $\mathrm{R}$ & $p$ & $\mathrm{R}$ & $p$ & $\mathrm{R}$ & $p$ & $\mathrm{R}$ & $p$ \\
\hline S T & & & & & & & & & & & & & 0.65 & 0.006 \\
\hline SS & -0.58 & 0.018 & -0.57 & 0.023 & -0.52 & 0.041 & & & & & & & & \\
\hline $\mathrm{SNO}_{3}$ & & & -0.57 & 0.022 & -0.62 & 0.011 & & & -0.66 & 0.005 & & & & \\
\hline $\mathrm{SNO}_{2}$ & & & & & & & & & -0.54 & 0.033 & & & -0.51 & 0.042 \\
\hline $\mathrm{SPO}_{4}$ & & & & & & & & & -0.50 & 0.048 & -0.50 & 0.048 & & \\
\hline BT & & & & & & & & & & & & & 0.50 & 0.049 \\
\hline $\mathrm{BNO}_{3}$ & & & -0.54 & 0.029 & & & & & -0.70 & 0.003 & -0.49 & 0.052 & & \\
\hline $\mathrm{BPO}_{4}$ & & & & & & & & & & & & & -0.51 & 0.046 \\
\hline SR & & & & & & & -0.57 & 0.02 & & & & & & \\
\hline RF & & & 0.51 & 0.045 & & & & & & & & & 0.52 & 0.041 \\
\hline
\end{tabular}

\begin{tabular}{|c|c|c|c|c|c|c|c|c|c|c|}
\hline \multirow[t]{2}{*}{ Parameters } & \multicolumn{2}{|c|}{ S. costatum } & \multicolumn{2}{|c|}{ Fragilariopsis sp. } & \multirow{2}{*}{$\frac{\text { T. subtilis }}{\mathrm{R}}$} & \multicolumn{3}{|c|}{ T. sp.2 } & \multicolumn{2}{|c|}{ C. curvisetus } \\
\hline & $\mathrm{R}$ & $p$ & $\mathrm{R}$ & $p$ & & $p$ & $\mathrm{R}$ & $p$ & $\mathrm{R}$ & $p$ \\
\hline SS & -0.69 & 0.003 & & & & & & & & \\
\hline SDO & & & & & 0.80 & 0.000 & & & 0.53 & 0.035 \\
\hline $\mathrm{SNO}_{3}$ & -0.52 & 0.039 & & & & & & & & \\
\hline $\mathrm{SSi}$ & & & 0.53 & 0.034 & & & & & & \\
\hline WV & & & & & & & 0.58 & 0.02 & & \\
\hline WD & & & 0.50 & 0.046 & & & & & & \\
\hline $\mathrm{SH}$ & & & -0.67 & 0.004 & & & & & & \\
\hline $\mathrm{RF}$ & 0.51 & 0.046 & & & & & & & & \\
\hline RH & & & 0.52 & 0.040 & & & & & & \\
\hline PR & & & -0.61 & 0.013 & & & & & & \\
\hline
\end{tabular}

\begin{tabular}{|c|c|c|c|c|c|c|}
\hline \multirow[t]{2}{*}{ Parameters } & \multicolumn{2}{|c|}{ S. costatum } & \multicolumn{2}{|c|}{ Fragilariopsis sp. } & \multicolumn{2}{|l|}{ T. subtilis } \\
\hline & $\mathrm{R}$ & $p$ & $\mathrm{R}$ & $p$ & $\mathrm{R}$ & $p$ \\
\hline $\mathrm{BDO}$ & & & -0.54 & 0.030 & & \\
\hline $\mathrm{BPO}_{4}$ & & & 0.61 & 0.012 & 0.50 & 0.050 \\
\hline BSi & & & 0.68 & 0.004 & & \\
\hline WD & & & 0.56 & 0.025 & & \\
\hline $\mathrm{SH}$ & & & -0.67 & 0.004 & & \\
\hline $\mathrm{RF}$ & 0.69 & 0.003 & & & 0.56 & 0.024 \\
\hline RH & & & 0.58 & 0.018 & & \\
\hline PR & & & -0.54 & 0.029 & & \\
\hline
\end{tabular}




\section{Legends to figures}

Fig. 1. Geographic location of the study site Zuari estuary (Goa), located on the west coast of India.

Fig. 2. Temporal variations in meteorological parameters. A) Wind speed, B) Wind direction, C) Day length, D) Solar radiation, E) Rainfall, F) Air temperature, G) Relative humidity and H) Atmospheric pressure. Shaded region represents monsoon season.

Fig. 3. Temporal variations in water parameters. A) Temperature, B) Salinity, C) Dissolved oxygen, D) Secchi disc depth, E) Nitrate $\left(\mathrm{NO}_{3}-\mathrm{N}\right)$, F) Nitrite $\left.\left(\mathrm{NO}_{2}-\mathrm{N}\right), \mathrm{G}\right)$ Phosphate $\left(\mathrm{PO}_{4}-\mathrm{P}\right)$ and $\mathrm{H})$ Silicate (Si). Shaded region represents monsoon season.

Fig. 4. Temporal variations in diatom abundance A) water column and B) sediment. Shaded region represents monsoon season. The error bars shown are standard deviations.

Fig. 5. Comparison between planktonic and benthic propagules of diatoms. A) Skeletonema costatum, B) Fragilariopsis sp., C) Thalassiosira spp. and D) Chaetoceros curvisetus

Fig. 6. Cluster dendrogams based on diatom abundance in Surface water (A and A'), Bottom waters (B and B') and sediments ( $\mathrm{C}$ and $\mathrm{C}^{\prime}$ ). Dendrograms (A, B and $\mathrm{C}$ ) of sampling periods using the Bray-Curtis similarity coefficient and group average method and Nonmetric Multidimensional scaling (NMDS) ordination based on the Bray-Curtis similarity coefficient (A', B' and C').

Fig. 7. Cluster dendrogams based on diatom abundance in Surface water (A and A'), Bottom waters (B and B') and sediments (C and C'). Species relationships (A, B and C) using Euclidean distance and group average method And Non-metric Multidimensional scaling (NMDS) ordination based on Euclidean distance of the DBP community (A', B' and C'). Note: Please see Table 1 for the details of the species abbreviations. 


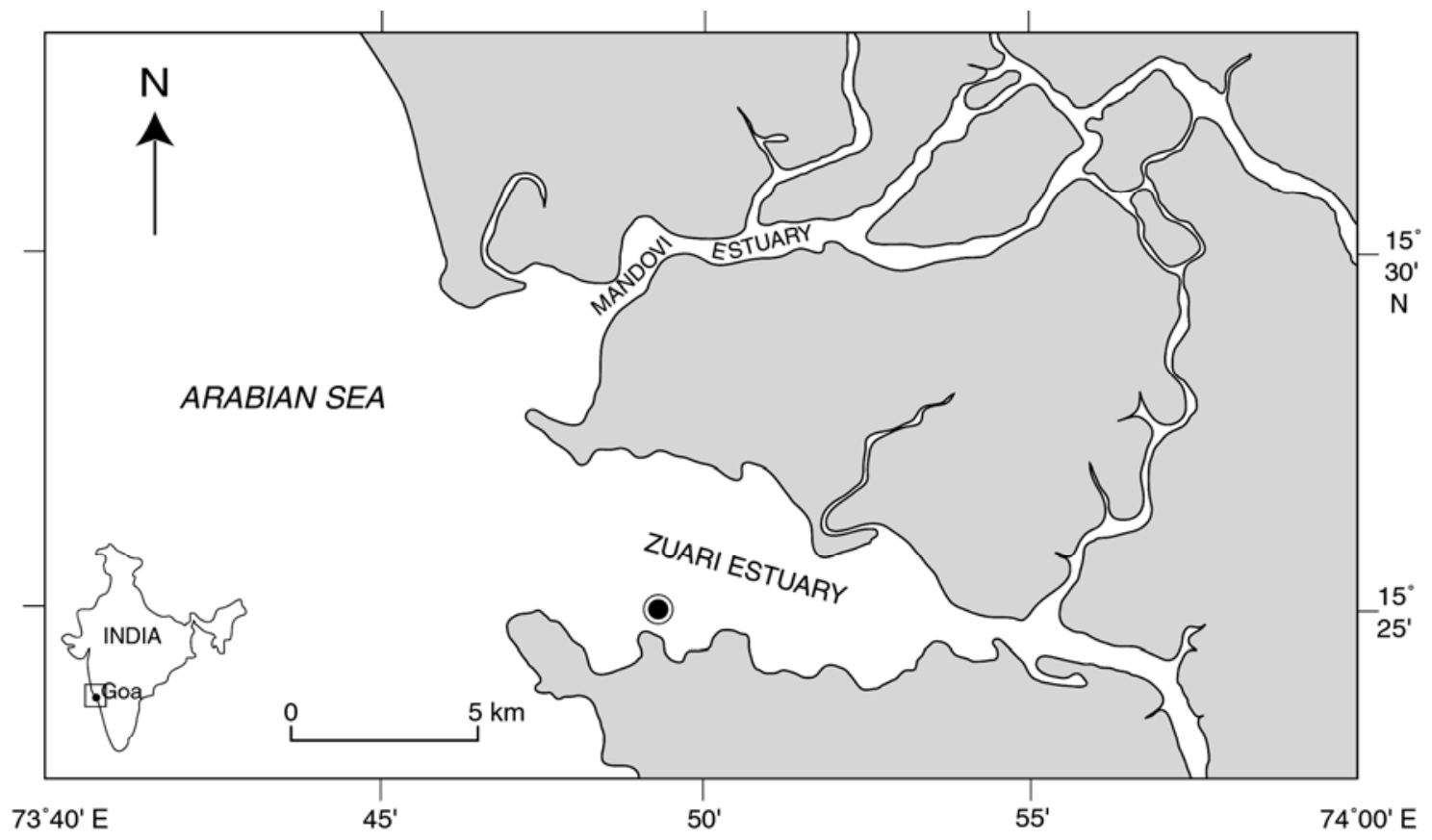

Fig. 1. 

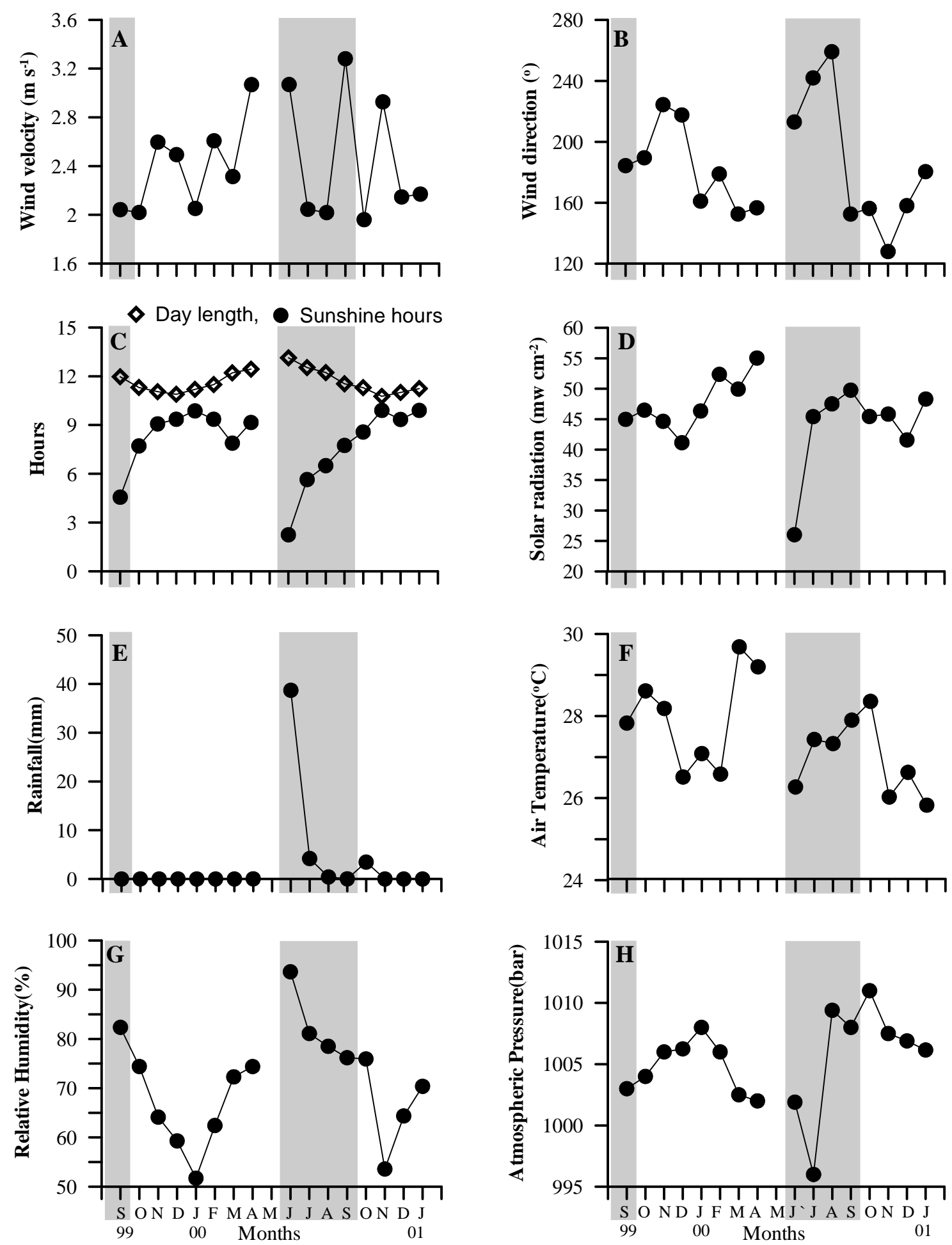

Fig. 2. 


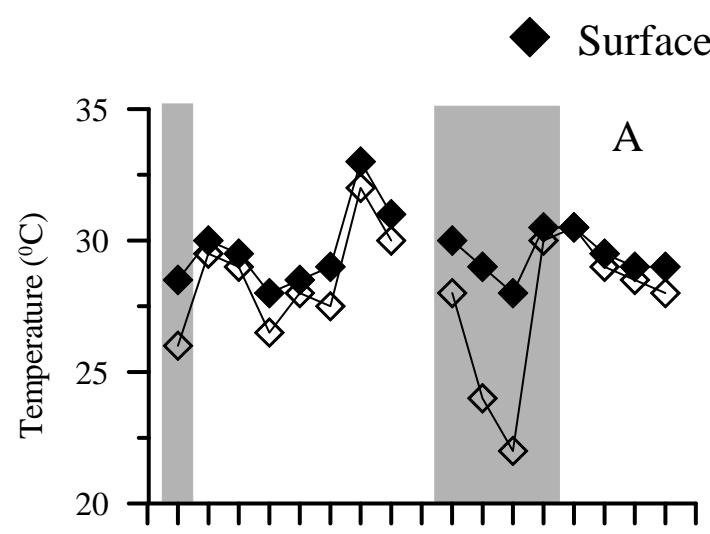

$\diamond$ Bottom
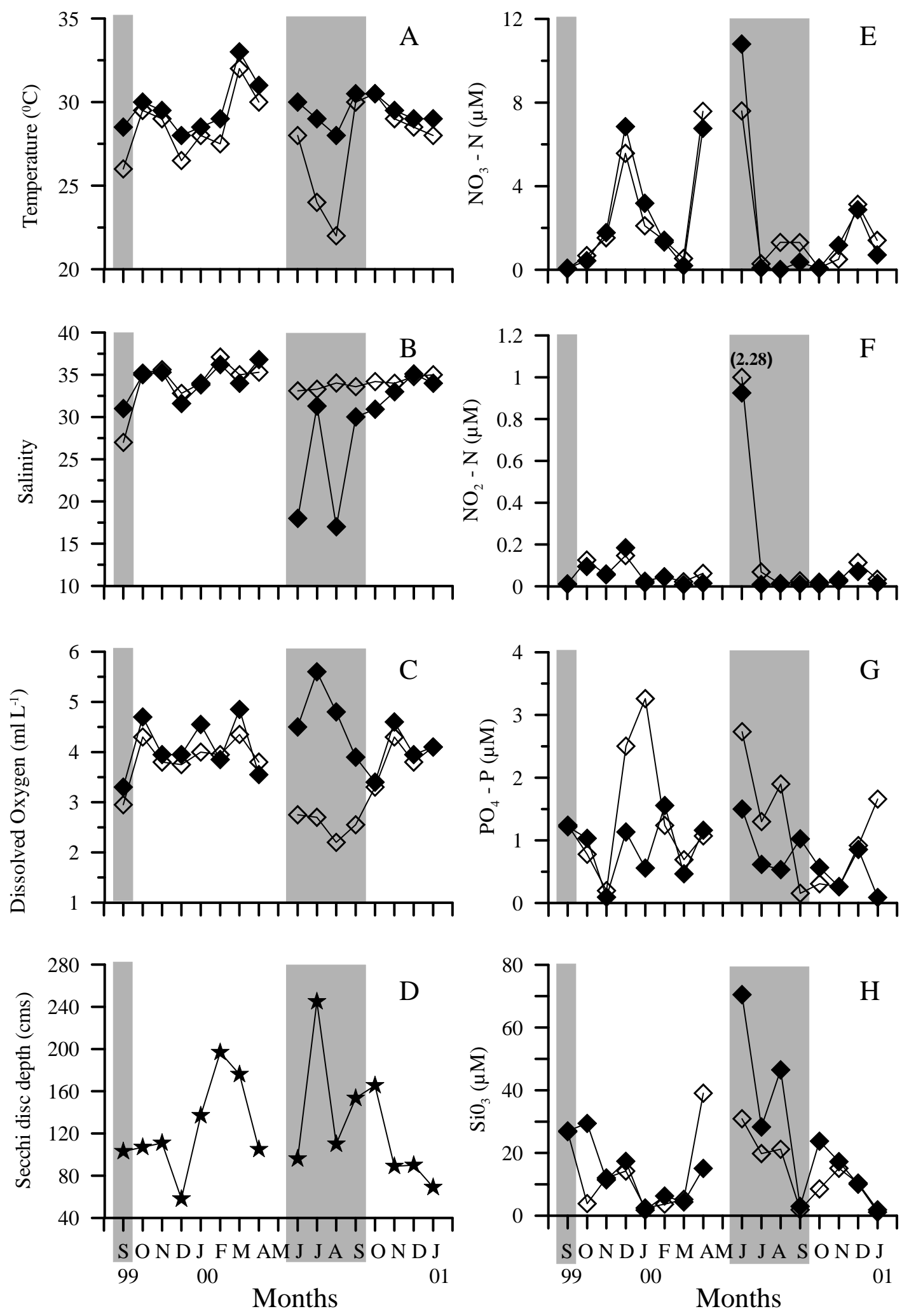

Fig. 3. 

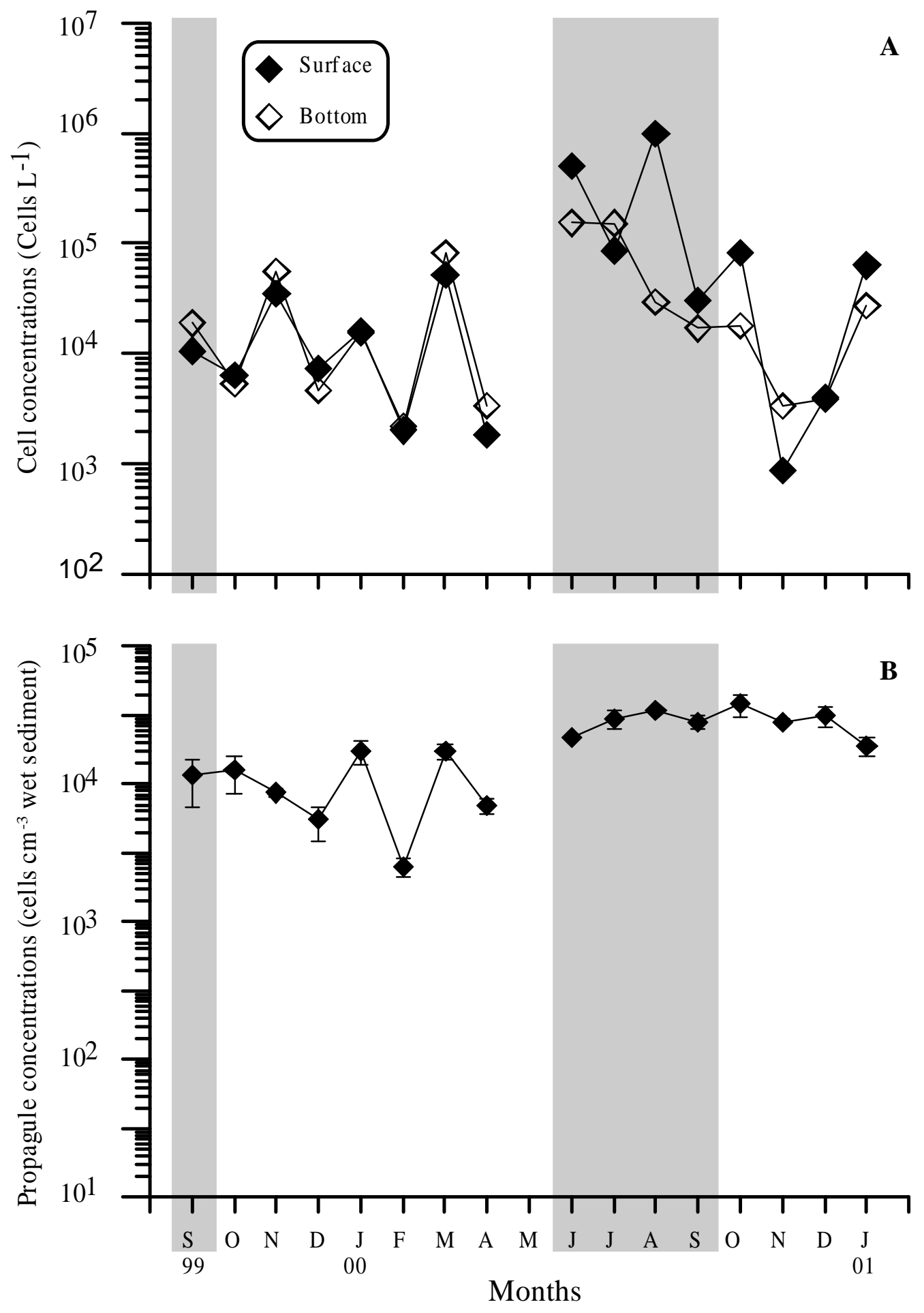

Fig. 4. 


\section{A. Skeletonema costatum}
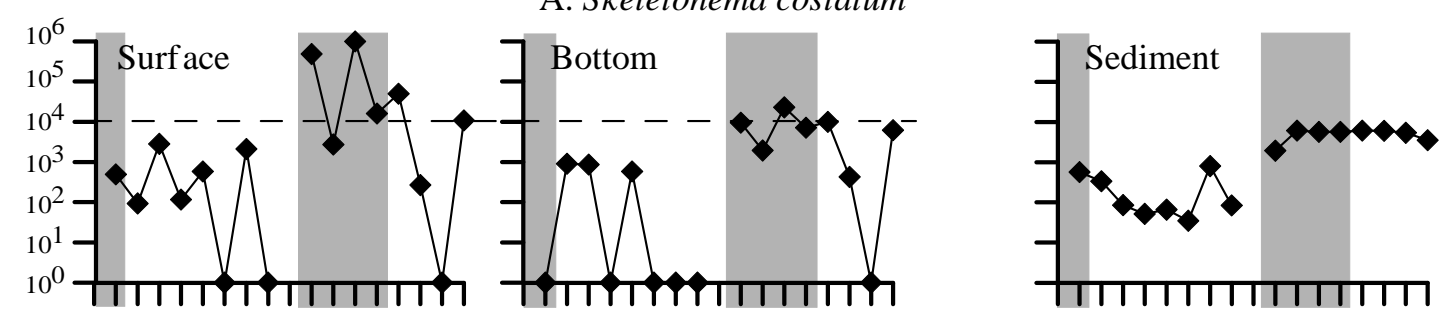

B. Fragilariopsis sp.
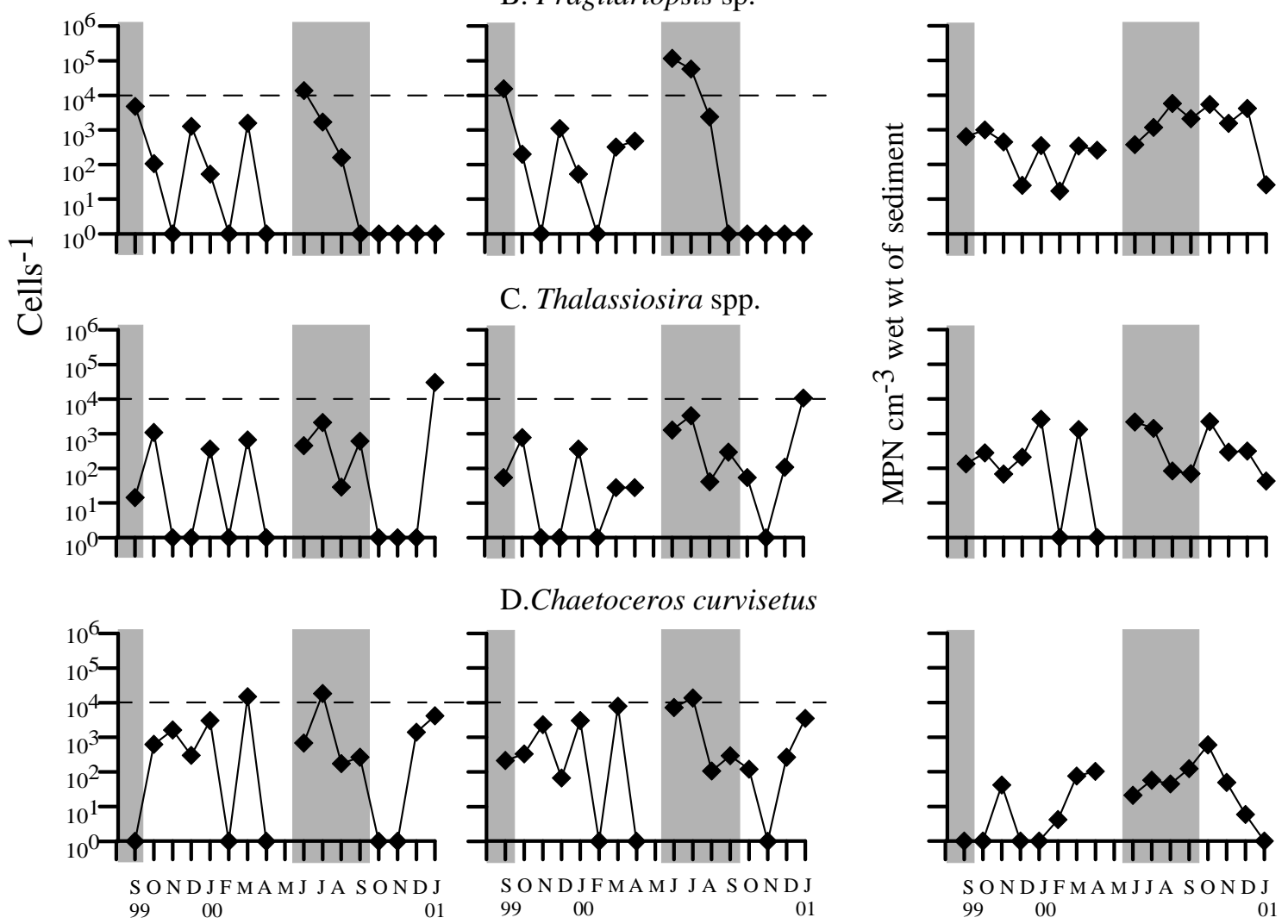

Chaetoceros curvisetus

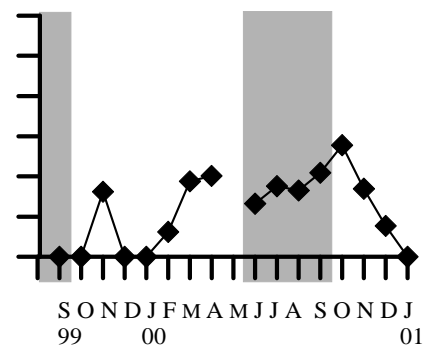

Months

Fig. 5. 

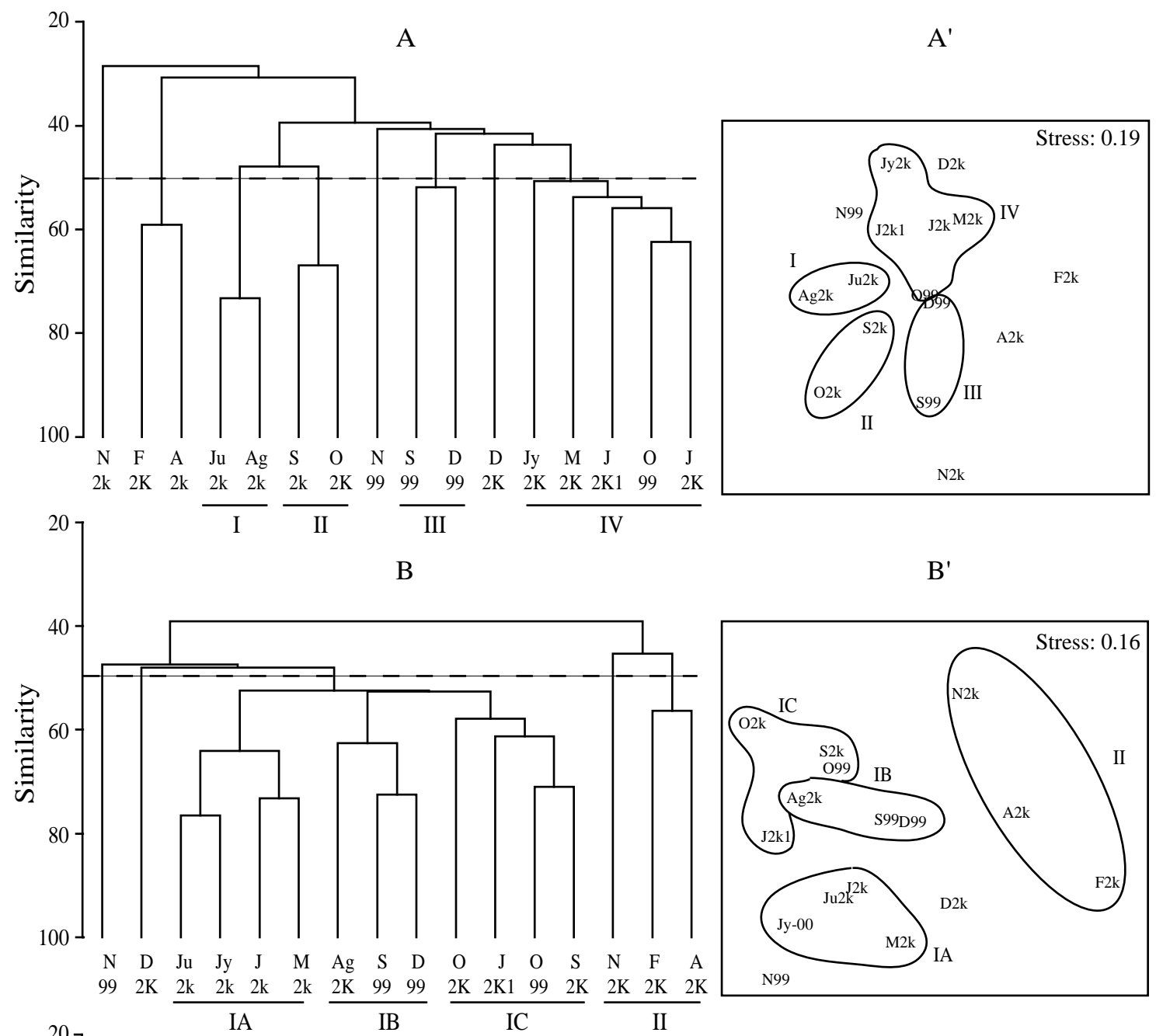

B'
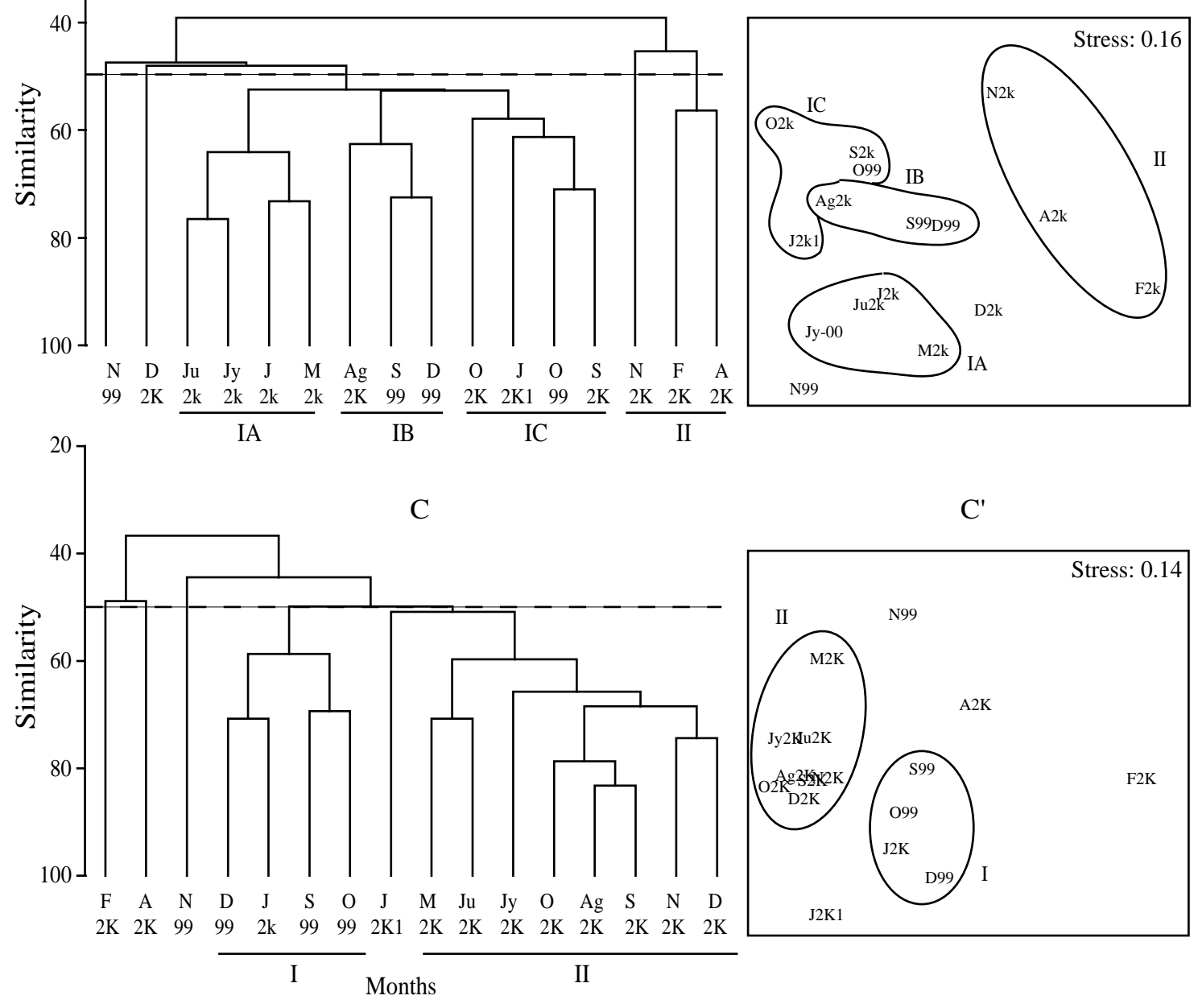

$\mathrm{C}^{\prime}$

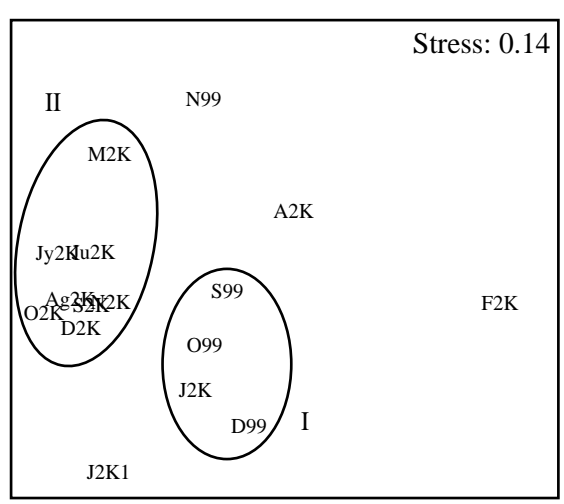

Fig. 6. 

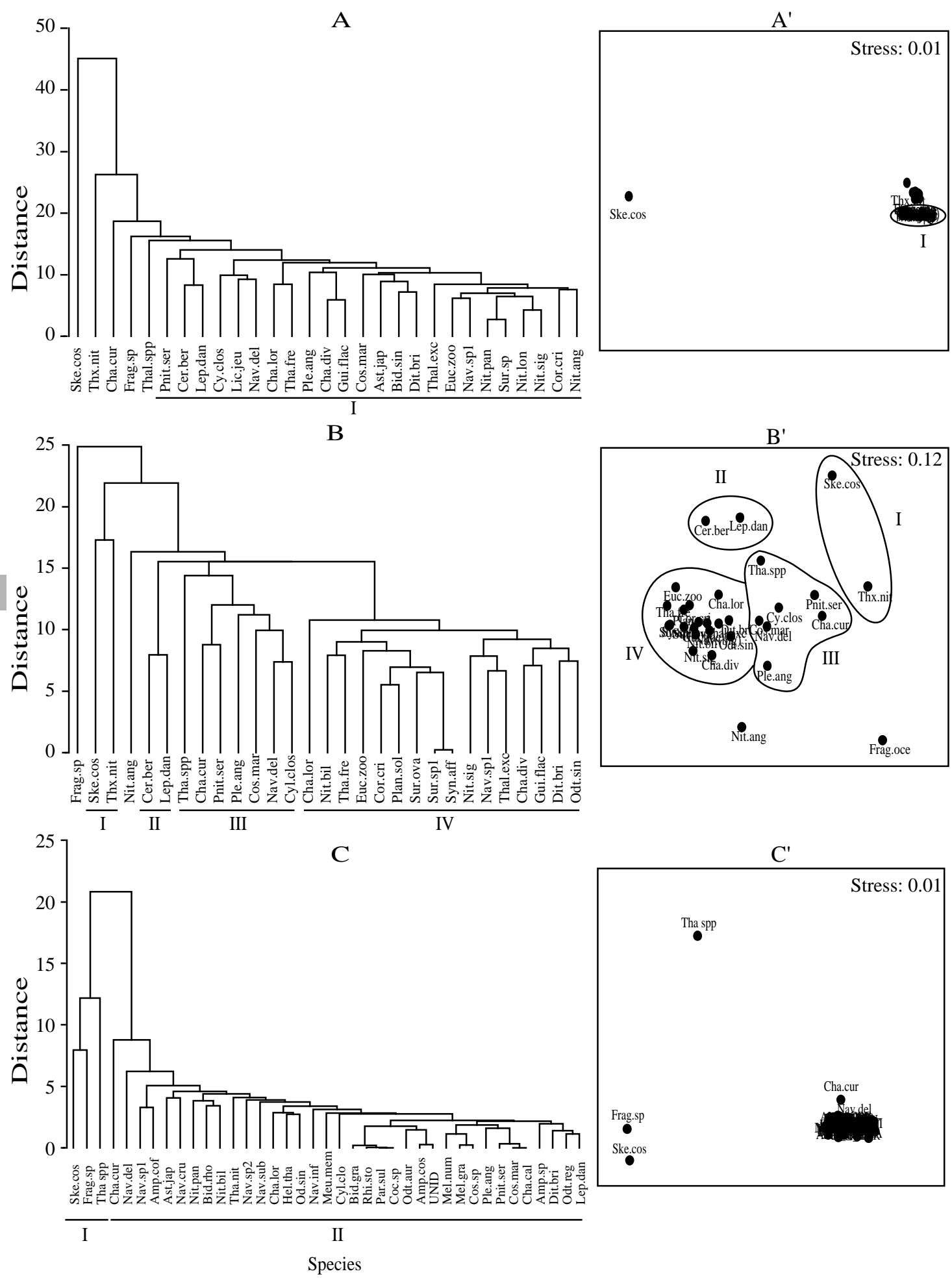

Fig. 7. 